\title{
Commentary on: Predictive value of health-related quality of life in progression of disability and depression in persons with multiple sclerosis: a 3-year study
}

\author{
Shailendra Kapoor
}

Received: 12 March 2013 / Accepted: 9 May 2013/Published online: 11 June 2013

(C) Belgian Neurological Society 2013

To the Editor,

Tepavcevic et al. [1] have provided interesting data in their recent article. Interestingly, a number of new biomarkers may help in detection and assessment of depression.

One emerging marker is platelet GSK3B activity. Patients with severe depression tend to demonstrate higher GSK3B activity [2]. Similarly, patients with co-existing impairment of cognition secondary to depression demonstrate higher GSK3B activity. Assessment of platelet adenylyl cyclase activity is another way to diagnose depression. In general, altered platelet adenylyl cyclase activity is observed in patients with more severe degree of depression [3].

Another emerging marker is interleukin-18. It is especially sensitive in detecting post-stroke depression. Serum interleukin-18 is usually measured a week after the stroke [4]. Interestingly, the risk of depression even half a year after the stroke can be predicted by assessing serum interleukin-18 levels. Beta-arrestin signaling complex is another emerging biomarker of depression [5]. Assessment of thyroid peroxidase antibody level is another way to assess for possible depression. This is an especially sensitive test to predict the chances of postpartum depression [6]. Similarly, elevated copper levels are seen in patients with depression making it a possible biomarker. Levels as high as $21 \%$ above normal have been seen in depression patients [7]. Similarly, assessment of serum zinc levels

This comment refers to the article available at doi:10.1007/s13760-013-0191-9.

S. Kapoor $(\square)$

Private Practice, Mechanicsville, VA, USA

e-mail: shailendrakapoor@yahoo.com helps in detecting treatment resistance in patients with depression [8].

The above examples briefly highlight the emerging new biomarkers of depression. Hopefully, the coming few years will see increased application of these markers.

\section{References}

1. Tepavcevic DK, Pekmezovic T, Stojsavljevic N et al (2013) Predictive value of health-related quality of life in progression of disability and depression in persons with multiple sclerosis: a 3-year study. Acta Neurol Belg (in press)

2. Diniz BS, Talib LL, Joaquim HP, de Paula VR, Gattaz WF, Forlenza OV (2011) Platelet GSK3B activity in patients with latelife depression: marker of depressive episode severity and cognitive impairment? World J Biol Psychiatry 12:216-222

3. Hines LM, Tabakoff B (2005) WHO/ISBRA study on state and trait markers of alcohol use and dependence investigators. Platelet adenylyl cyclase activity: a biological marker for major depression and recent drug use. Biol Psychiatry 58:955-962

4. Yang L, Zhang Z, Sun D, Xu Z, Zhang X, Li L (2010) The serum interleukin-18 is a potential marker for development of post-stroke depression. Neurol Res 32:340-346

5. Schreiber G, Golan M, Avissar S (2009) Beta-arrestin signaling complex as a target for antidepressants and as a depression marker. Drug News Perspect 22:467-480

6. Kuijpens JL, Vader HL, Drexhage HA, Wiersinga WM, van Son MJ, Pop VJ (2001) Thyroid peroxidase antibodies during gestation are a marker for subsequent depression postpartum. Eur $\mathrm{J}$ Endocrinol 145:579-584

7. Schlegel-Zawadzka M, Zieba A, Dudek D, Zak-Knapik J, Nowak G (1999) Is serum copper a "trait marker" of unipolar depression? A preliminary clinical study. Pol J Pharmacol 51:535-538

8. Maes M, Vandoolaeghe E, Neels H et al (1997) Lower serum zinc in major depression is a sensitive marker of treatment resistance and of the immune/inflammatory response in that illness. Biol Psychiatry 42:349-358 